\title{
Europe studies contingency plans for withdrawal from space station
}

Paris. Europe's plans to participate in the international space station being planned by the US National Aeronautics and Space Administration (NASA) were placed in doubt this week when officials from the European Space Agency (ESA) announced that the agency is thinking of redesigning its planned hardware contributions so that they could be used independently of the station.

If the proposal is accepted by the ESA council, the development of the agency's main contribution to the space station, an attached pressurized module (APM), would be virtually frozen until ESA ministers decide on its fate at their next meeting, due to take place in February 1995.

The need for cutbacks has been precipitated by the difficulties faced by several ESA member states in meeting their contributions to the agency's programmes. Speaking in Paris this week, Jean-Marie Luton, the agency's director-general, explained that something has to give, and that the pressurized module is the "only candidate".

By freezing further development work on the module until 1995, and
by making design

IMAGE UNAVAILABLE by making design FOR COPYRIGHT REASONS would be able to cut its cost over the period 1994-2000 from Ecu 1.82 billion (US\$ 2.2 billion) to Ecu 1.32 billion.

Jean-Marie Luton

But the main "something must give" reason for proposing the move is growing uncertainty over Europe's role in the international space station Alpha - the name of final redesign of space station Freedom - and the consequent need for the European agency to make

\section{US keeps out of THORP debate}

Washington. The Clinton administration has decided to steer clear of the debate over whether Britain's Thermal Oxide Reprocessing Plant (THORP) at Sellafield in Cumbria should be allowed to start operation, thus defying pressure from environmentalists and some Congressmen.

In revealing his policy on nuclear nonproliferation to the United Nations in New York on Monday, President Bill Clinton concentrated on the need to control military plutonium and missile delivery technology. He ignored calls for the United States to come out against the opening of civil reprocessing facilities - such as THORP which produce plutonium.

The British government's consultation period on the future of THORP ends on October 4, and opponents of the plant have been pushing for input from the US to that process to reinforce their opposition.

Earlier this month, for example, the House of Representatives passed a "sense of Congress" motion put forward by Joe Kennedy (Democrat, Massachusetts) stating that "the start-up or continued operation of any plutonium separation plant ... should be suspended until related environmental and proliferation concerns have been resolved."

Kennedy has also given his support to a bill introduced by Pete Stark (Democrat, California) which urges the President to take the issue to the UK government "in high-level bilateral discussions" before its review of THORP is completed. The bill points out that THORP will produce 59 tonnes of plutonium in ten years, to add to the world's existing stockpile of 910 tonnes. But it stands little chance of becoming law.

Recognizing that time is short, $31 \mathrm{mem}$ bers of Congress signed a letter to Clinton late last week urging him to enter "immediate consultations with Britain, urging that Thorp not begin operations". But White House officials say that their position reflects the State Department's view that the THORP decision is a matter for the British government and its main customers in Germany and Japan.

Critics of that position argue that under the US-Japan nuclear cooperation agreement of 1988, the United States is ultimately responsible for the large, Japanese portion of THORP's throughput, and is therefore entitled to a say in the THORP decision.

They claim backing from the non-proliferation office of the US Department of Defense, and claim that despite its public position, the administration will eventually work behind the scenes to press Britain and Japan to reduce production of civil plutonium.

Meanwhile a high court ruling was expected in London yesterday (Wednesday) on whether the environmental group Greenpeace has the legal right to seek a judicial review of an earlier decision to let British Nuclear Fuels plc begin tests on the THORP plant.
Colin Macilwain contingency plans.

Following an agreement announced earlier this month, the United States now seems likely to drop its plans to build Alpha, and instead combine it with Russia's planned MIR2 station to create a single "Global Space Station (GSS)". The GSS is likely to have an orbit at an inclination of $51.6 \mathrm{de}$ grees, rather than the 28.2 degrees originally planned for Freedom.

Europe's participation in Alpha was assured to some degree under an intergovernmental agreement. Romano Barbero, head of the APM programme at ESA, says the United States acknowledges that it must consider the large Russian participation as an extension of its original agreement with its international partners in Alpha. He says that ESA will be negotiating to "safeguard our rights and costs as they are at the moment".

At the same time, Luton warns that Europe would be forced to withdraw from the programme unless the United States agrees to renegotiate FSA's contribution to the running costs of a station. Reinforcing this message, ESA's new plans for its pressurized module, as well as for spacecraft being developed for use with the station, envisage redesigning them so that they can be used in "a scenario without any significant participation in an international space station".

The mechanical and electronic aspects of the pressurized module would be redesigned so that it could be operated from Europe, says Barbero. It would also be reduced in size so that it could be put into orbit using the planned European Ariane V rocket, instead of NASA's space shuttle.

ESA's ministers will decide whether to proceed with the redesigned APM at their next meeting in February 1995. If the redesign does go ahead, the module would be launched in 2002, three years later than planned. The ministers will decide at the same meeting on the future of two nonreusable crew and cargo vehicles from the Hermes programme.

European hesitancy over the shape of the new, global space station will add to renewed concerns in Washington about the lack of detail which has emerged on it so far.

US funding for the space station is secure for another year after the Senate last week followed the House and voted down an attempt by Dale Bumpers (Democrat, Arkansas) to kill the programme. But four influential station supporters in Congress have written to vice-president Al Gore expressing their concerns about its impact on US jobs and on existing agreements with Canada, Europe and Japan. Declan Butler 